\title{
Lysimachia congestiflora 'Zimai': An Ornamental Plant with Purple-veined Leaves
}

\author{
Wei Zheng ${ }^{1}$ \\ College of Modern Agricultural Engineering, Kunming University of Science \\ and Technology, Kunming 650224, P.R. China; and Key Laboratory of \\ Horticultural Plant Biology (Huazhong Agricultural University), Ministry of \\ Education, Wuhan 430070, P.R. China \\ Xiao-Dan Xu \\ College of Modern Agricultural Engineering, Kunming University of Science \\ and Technology, Kunming 650224, P.R. China
}

\section{Long-Qing Chen ${ }^{1}$}

Key Laboratory of Horticultural Plant Biology (Huazhong Agricultural University), Ministry of Education, Wuhan 430070, P.R. China

Additional index words. dense-flowered loosestrife, color vein, ground cover

Dense-flowered loosestrife (Lysimachia congestiflora Hemsl.), a mat-forming perennial herb, is native throughout much of south, southwest, and central China with a subtropical continental monsoon climate (Chen and $\mathrm{Hu}$, 1989). The species is as a semievergreen herb in central China; in south China, it develops as an evergreen plant. It grows within a wide altitudinal range from sea level to $2100 \mathrm{~m}$ in dankness in forest edges or roadsides (Chen and $\mathrm{Hu}, 1989)$. L. congestiflora is a quantitative long-day plant (Zhang et al., 1995) and blooms from April to October in Zone 7 (U.S. Dept. of Agriculture, 1990). The species is famous both as an ornamental plant and a Chinese herbal medicine (Zheng et al., 2009). It is currently marketed as a bedding plant, hanging basket, and potted plant in North America and Europe. As an ornamental plant, L. congestiflora is grown primarily for its creeping stems as well as its terminal cluster of bright yellow flowers and green foliage.

In recent years, new cultivars of $L$. congestiflora, especially colored-leaf cultivars such as Eco Dark Satin, Golden Falls, Outback Sunset, Persian Carpet, Persian Chocolate, Silver Bird, Sunbeam, Sunset Gold, Walkabout Sunset, and Zidie, have been released. However, no plants of L. congestiflora with purple venation leaves have been introduced. This article reports on a new cultivar of $L$. congestiflora, Zimai, which has been selected for its striking purple vein compared with the typical species.

\footnotetext{
Received for publication 21 June 2010. Accepted for publication 26 July 2010 .

${ }^{1}$ To whom reprint requests should be addressed; e-mail yedizhw@yahoo.com.cn
}

\section{Origin}

In 2006, several plants of L. congestiflora were collected in the Yangtze River Basin in an effort to select plants with superior landscape characteristics. The collected plants were grown at Huazhong Agriculture University Nursery (long. $30^{\circ} 28^{\prime} \mathrm{N}$, lat. $114^{\circ} 21^{\prime} \mathrm{E}$ ) for selection. One plant discovered at Lushan (Jiangxi Province) was judged as having attractive purple veins compared with other plants observed. To determine its commercial value, cuttings of the selected plant were sent to Huangshi Nursery (long. $30^{\circ} 10^{\prime} \mathrm{N}$, lat. $115^{\circ} 02^{\prime}$ E) and Xianning Nursery (long. $29^{\circ} 51^{\prime} \mathrm{N}$, lat. $114^{\circ} 20^{\prime} \mathrm{E}$ ) in central China for further evaluation in 2007. After 3 years of growth, the plants continued to retain their foliage color. In accordance with the International Code of Nomenclature for Cultivated Plants, the name 'Zimai' was selected to indicate the vein color of the plant (Brickell et al., 2004). Voucher specimens (Zheng and Chen 0810) were deposited at the herbarium of Huazhong Agriculture University.

\section{Description}

L. congestiflora 'Zimai' has a uniform and creeping growth habit with 5 to $15 \mathrm{~cm}$ of canopy thickness. Its dark purple-red [Royal Horticulture Society (RHS), 1986) 187C] stems are 20 to $40 \mathrm{~cm}$ long, and its branches and roots ascend at the basal nodes. The surface of the stems and leaves has some white (RHS 157B) hairs with a length of 1 to $2 \mathrm{~mm}$. The leaves are ovate or cordate (Fig. 1), opposite, and up to $2.8 \mathrm{~cm}$ long $\times 2.2 \mathrm{~cm}$ wide. They also have dark purple-red (RHS 185B) venation on more than $34.2 \% \pm 3.5 \%$ of the leaf area. Flowering occurs in late spring and lasts $\approx 30 \mathrm{~d}$. The peak flowering stage in China appears in May with $378.3 \pm 41.5$ flowers $/ \mathrm{m}^{2}$. The constrictive raceme has six to 15 flowers shaped like bells, which are 1.4 to $1.6 \mathrm{~cm}$ in diameter (Fig. 2). The corolla is yellow (RHS 13B) with a red (RHS 41B) base. The corolla tube is 2 to $4 \mathrm{~mm}$ long, and the petals are elliptical, which are up to $1.6 \mathrm{~cm}$ long $\times 0.7 \mathrm{~cm}$ wide.

\section{Performance}

The performance of $L$. congestiflora 'Zimai' under different shade levels was evaluated at Huazhong Agriculture University Nursery in central China. Growth tests were initiated using well-rooted and threenode terminal cuttings. Each of the 50 cuttings was grown under $75 \%, 47 \%, 22 \%$, or $0 \%$ shade (maximum light intensity was $818.3 \mathrm{umol} \cdot \mathrm{m}^{-2} \cdot \mathrm{s}^{-1}$ in March) in a completely randomized design. Light was limited by covering the outdoor plots with a voile net or black woven shadecloth. The experiment was conducted in yellow brown sandy loam with regular irrigation ( 3 to $5 \mathrm{~L} \cdot \mathrm{m}^{-2}$ per irrigation, one to three irrigations per week), fortnightly fertilization [with nitrogen $(\mathrm{N})$ at $3.3 \mathrm{~g} \cdot \mathrm{m}^{-2}$ first and later $\mathrm{N}$ at $4.4 \mathrm{~g} \cdot \mathrm{m}^{-2} 16 \mathrm{~N}-$ $8 \mathrm{P}-16 \mathrm{~K}]$, roguing of weeds when necessary, and a temperature range of 8 to $33{ }^{\circ} \mathrm{C}$. After $60 \mathrm{~d}$ (from 10 Mar. to 10 May 2009), data were recorded, including the number of branches, leaves, and flowers, average length of the main stem and internodes, and shoot dry weight per plant.

The plants were grown in the field $\left(50 \mathrm{~m}^{2}\right.$ with full sun) of Huazhong Agriculture University Nursery, Huangshi Nursery, and Xianning Nursery with regular irrigation (3 to $5 \mathrm{~L} \cdot \mathrm{m}^{-2}$ per irrigation, one to three, two to six, and zero to two irrigations per week in spring, summer and fall, and winter, respectively), monthly fertilization (with $\mathrm{N}$ at 3.3 $\mathrm{g} \cdot \mathrm{m}^{-2}$ in March and September and $\mathrm{N}$ at 4.4 $\mathrm{g} \cdot \mathrm{m}^{-2} 16 \mathrm{~N}-8 \mathrm{P}-16 \mathrm{~K}$ in other months) and hand roguing of weeds when necessary from 2007 to 2009 for additional evaluation, including disease and pest susceptibility, reseeding or invasiveness, heat tolerance in July (over 3 years: average temperature of $29.8^{\circ} \mathrm{C}$; maximum temperature of $39.7{ }^{\circ} \mathrm{C}$ ), and freezing tolerance in January (average temperature of $2.0{ }^{\circ} \mathrm{C}$; minimum temperature of $-5.3{ }^{\circ} \mathrm{C}$ ). Performance was evaluated by the proportion of vigorous leaves and visual quality ratings (scores of " 1 ," " 3 ," or " 5 " for poor, acceptable, or excellent quality, respectively). The panel of quality evaluators was composed of 17 postgraduates (five doctors and 12 masters) from Key Laboratory of Horticultural Plant Biology (Huazhong Agricultural University). L. congestiflora 'Zidie', wild-type $L$. congestiflora, and L. nummularia 'Aurea' were used as the control plants. Data were analyzed using analysis of variance and Duncan's multiple range test. Proportion of vigorous leaves (\%) was subjected to arcsine transformation for statistical analysis.

Shade levels had a strong influence on the growth and flowering of 'Zimai', although the species grew well under different levels 
of shade (Table 1). Leaf area and length of the main stem increased with the increase in shade; meanwhile, the number of leaves and flowers and the shoot dry weight decreased with the increase in shade levels. The number of branches and internode length showed no obvious difference across levels of shade. Leaf color was affected by shade as well; the veins under full sun were dark purple-red (RHS $185 \mathrm{~B})$; in $75 \%$ shade, they were dark purplebrown (RHS 187A). Thus, full sun is better for a bright leaf color and to obtain abundant leaves and flowers; it results in the best growth and ornamental quality for 'Zimai'.

L. congestiflora 'Zimai' showed strong resistance in hot summer and freezing winter conditions. During hot days in July, the proportion of vigorous leaves of 'Zimai' showed no significant difference with $L$. congestiflora 'Zidie' and wild-type L. congestiflora but were significantly greater than those of L. nummularia 'Aurea' as shown by Duncan's multiple range tests (Table 2). This result indicates that the heat tolerance capability of 'Zimai' was similar to 'Zidie' and wild-type L. congestiflora but stronger than that of 'Aurea'. During the freezing days of January, the proportion of vigorous leaves of 'Zimai', 'Zidie', and wild-type L. congestiflora were significantly greater than that of 'Aurea' suggesting that the former exhibited stronger freezing tolerance than the latter (Table 2). Although the leaves on the stem base were injured by continuous snow cover for $30 \mathrm{~d}$ in Jan. 2008 (Fu et al., 2008), the plants recovered quickly the next spring. In conclusion, 'Zimai' exhibited strong heat and freezing tolerance.

During the experimental years, 'Zidie' had colorful leaves (Zheng et al., 2009), 'Zimai' had purple-veined leaves, wild-type L. congestiflora had green leaves, whereas L. nummularia 'Aurea' had many white sun-bleached leaves. Thus, the quality degree of four tested plants in July was: 'Zidie' > 'Zimai' > wild-type L. congestiflora > 'Aurea' (Table 2). In January, however, they were equivalent, because all of their partial basal leaves perished.

In other aspects, 'Zimai' was free of major diseases and pest. The plant spread by its creeping stems but exhibited little invasiveness because no seed was obtained in the field.

\section{Culture and Use}

'Zimai' was readily propagated through creeping stem cuttings. When the temperature was up to $15{ }^{\circ} \mathrm{C}$, more than $98 \%$ of cuttings started rooting from their basal nodes within $10 \mathrm{~d}$ of covering by transparent polythene film to keep the temperature and high humidity of the soil surface. For ground cover, 'Zimai' can be grown under full sun to partial shade in yellow brown soil or sandy soil with regular irrigation. For potted plants or hanging baskets, it can be planted in the substrate with equal volumes of vermiculite or perlite and humus soil and fertilized with $\mathrm{N}$

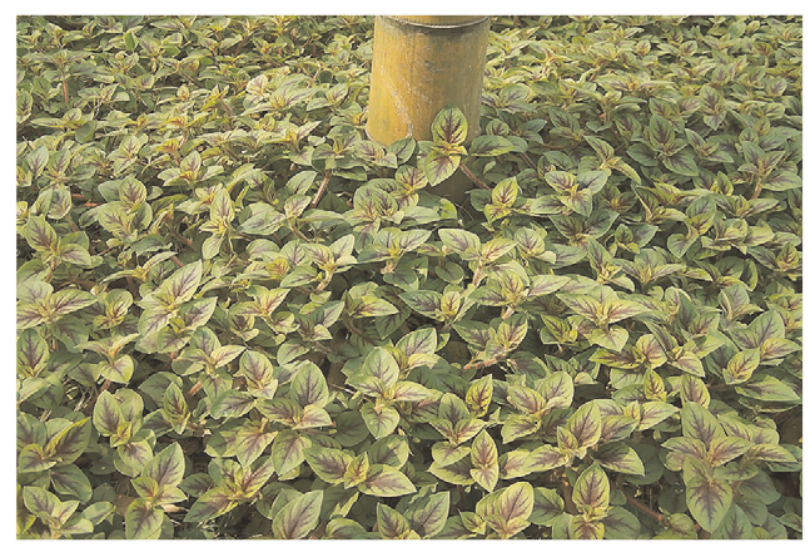

Fig. 1. L. congestiflora 'Zimai' used as ground cover in Apr. 2009.

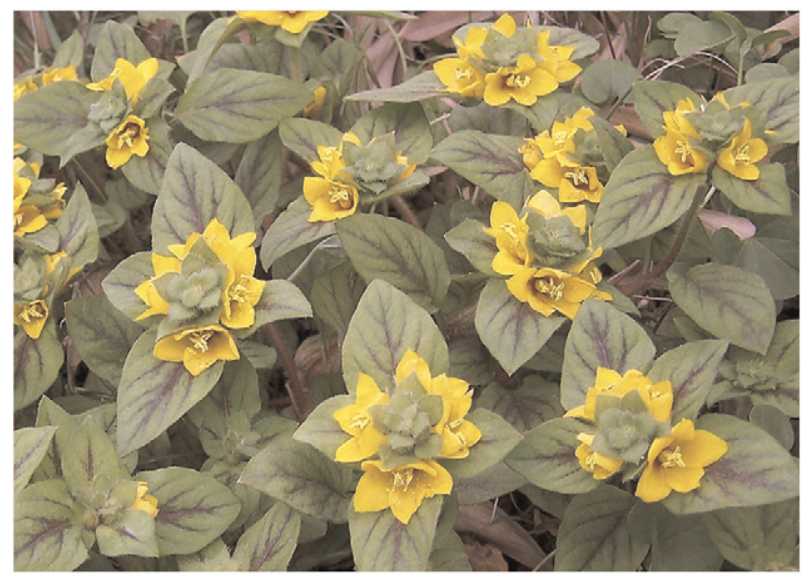

Fig. 2. The flowering plants of L. congestiflora 'Zimai' in May 2009.

Table 1. Performance of $L$. congestiflora 'Zimai' under different shade levels.

\begin{tabular}{lccccccc}
\hline $\begin{array}{l}\text { Shade } \\
(\%)\end{array}$ & $\begin{array}{c}\text { Length of the } \\
\text { internode }(\mathrm{cm})\end{array}$ & $\begin{array}{c}\text { Area of } \\
\text { leaves }\left(\mathrm{cm}^{2}\right)\end{array}$ & $\begin{array}{c}\text { Length of the } \\
\text { main stem }(\mathrm{cm})\end{array}$ & $\begin{array}{c}\text { No. of } \\
\text { branches }\end{array}$ & $\begin{array}{c}\text { No. of } \\
\text { leaves }\end{array}$ & $\begin{array}{c}\text { No. of } \\
\text { flowers }\end{array}$ & $\begin{array}{c}\text { Shoot dry } \\
\text { wt }(\mathrm{g})\end{array}$ \\
\hline $0^{\mathrm{z}}$ & $2.5 \mathrm{a}^{\mathrm{y}}$ & $4.5 \mathrm{c}$ & $27.9 \mathrm{~b}$ & $34.9 \mathrm{a}$ & $356.7 \mathrm{a}$ & $22.5 \mathrm{a}$ & $4.3 \mathrm{a}$ \\
22 & $2.5 \mathrm{a}$ & $5.4 \mathrm{bc}$ & $28.2 \mathrm{~b}$ & $35.8 \mathrm{a}$ & $302.0 \mathrm{~b}$ & $23.6 \mathrm{a}$ & $3.8 \mathrm{~b}$ \\
47 & $2.8 \mathrm{a}$ & $6.2 \mathrm{~b}$ & $33.8 \mathrm{a}$ & $36.3 \mathrm{a}$ & $296.1 \mathrm{~b}$ & $18.6 \mathrm{~b}$ & $3.5 \mathrm{~b}$ \\
75 & $2.9 \mathrm{a}$ & $7.3 \mathrm{a}$ & $34.8 \mathrm{a}$ & $35.4 \mathrm{a}$ & $278.7 \mathrm{c}$ & $16.9 \mathrm{~b}$ & $2.9 \mathrm{c}$ \\
\hline
\end{tabular}

${ }^{\mathrm{z}}$ Maximum light intensity was $818.3 \mu \mathrm{mol} \cdot \mathrm{m}^{-2} \cdot \mathrm{s}^{-1}$ in March.

${ }^{\mathrm{y}}$ Mean values in columns followed by the same letter indicate no significant difference at $P<0.05$ using Duncan's multiple range tests.

Table 2. Performance of L. congestiflora 'Zimai' in July and January. ${ }^{\mathrm{z}}$

\begin{tabular}{|c|c|c|c|c|}
\hline \multirow[b]{2}{*}{ Cultivar } & \multicolumn{2}{|c|}{ Vigorous leaves (\%) } & \multicolumn{2}{|c|}{ Quality $^{\mathrm{y}}$} \\
\hline & July & January & July & January \\
\hline L. congestiflora 'Zimai' & $96.7 \mathrm{a}^{\mathrm{x}}$ & $48.7 \mathrm{a}$ & 4.5 & 2.5 \\
\hline L. congestiflora 'Zidie' & $97.2 \mathrm{a}$ & $45.2 \mathrm{a}$ & 4.8 & 2.3 \\
\hline L. congestiflora & $96.1 \mathrm{a}$ & $46.5 \mathrm{a}$ & 3.6 & 2.4 \\
\hline L. nummularia 'Aurea' & $26.3 \mathrm{~b}$ & $14.4 \mathrm{~b}$ & 1.4 & 2.2 \\
\hline
\end{tabular}

${ }^{\mathrm{z}}$ Mean values of five replications ( $1 \mathrm{~m}^{2}$ of plants each) per year and averaged over 3 years (2007 to 2009) with average temperature of $29.8^{\circ} \mathrm{C}$ and maximum temperature of $39.7^{\circ} \mathrm{C}$ in July and average temperature of $2.0^{\circ} \mathrm{C}$ and minimum temperature of $-5.3{ }^{\circ} \mathrm{C}$ in January.

${ }^{\mathrm{y}}$ Visual rating: 1 = poor, 3 = acceptable, 5 = excellent quality (not analyzed statistically).

${ }^{\mathrm{x}}$ Mean values in columns followed by the same letter indicate no significant difference at $P<0.05$ using Duncan's multiple range tests.

at 50 ppm $15 \mathrm{~N}-9.9 \mathrm{P}-14.1 \mathrm{~K}$ when necessary. The plant can develop as an evergreen plant in the greenhouse when the lowest temperature is greater than $5{ }^{\circ} \mathrm{C}$. It can be grown in central China and warmer places as well as other regions with a similar climate.

\section{Availability}

The patent application of $L$. congestiflora 'Zimai' will be submitted to the Patent Office of Hubei Province, China. The patent rights will be assigned to Huazhong Agriculture 
University. Inquiries regarding 'Zimai' can be made by sending an e-mail to yedizhw@ yahoo.com.cn. Plants for research purposes may be obtained directly from the author.

\section{Literature Cited}

Brickell, C.D., B.R. Baum, W.L.A. Hetterscheid, A.C. Leslie, J. McNeill, P. Trehane, F. Vrugtman, and J.H. Wiersema. 2004. International code of nomenclature for cultivated plants, 7th ed. Acta Hort. 647:1-84.

Chen, F.H. and C.M. Hu. 1989. Flora of China. Science Press, Beijing. 59:83-84.

Fu, J.J., S.L. Li, and Y.M. Wang. 2008. Influence of prior thermal state of global oceans on the formation of the disastrous snowstorm in Jan. 2008. Clim. Environ. Res. 13:478490.

Royal Horticulture Society. 1986. RHS colour chart. Royal Hort. Soc., London, UK.
U.S. Dept. of Agriculture. 1990. USDA Miscellaneous Publication No. 1475. 10 May 2010. <http:// www.usna.usda.gov/Hardzone/ushzmap.html>

Zhang, D., A.M. Armitage, J.M. Affolter, and M.A Dirr. 1995. Environmental control of flowering and growth of Lysimachia congestiflora Hemsl. HortScience 30:62-64.

Zheng, W., X.Q. Liu, and L.Q. Chen. 2009. Lysimachia congestiflora 'Zidie'-An ornamental plant with fancy leaves. HortScience 44:17711772. 